\title{
Role of Plasma-rich Fibrin in the Management of Intrusion Injuries of Teeth
}

\author{
Rajesh Ragulakollu ${ }^{1}$, Nandini Biradar ${ }^{2}$, Gururam T Kukkunuru ${ }^{3}$, Gonuguntla Sudhir ${ }^{4}$, Chittaranjan Bogishetty ${ }^{5}$, \\ Vamsikrishna Reddy ${ }^{6}$
}

\begin{abstract}
Aim and objective: To establish a new method of treating severe type of intrusion type of injuries to teeth. The prognosis of these injuries is poor. Poor prognosis is attributed to the development of multiple complications from various components of teeth. We described the various phases to prevent and treat various complications.

Background: Most common sequelae to intrusion injuries are alveolar bone loss, resorption of teeth, and gingival recession. Plasma-rich fibrin (PRF) possesses various biological elements for optimal healing and prevention of the above.

Case description: A 9-year-old female patient suffered intrusion injury to 21 with no root fractures. Since intrusion was severe type, surgical repositioning with flexible splinting is done. Complications such as alveolar bone loss and gingival recession have occurred, which were successfully treated with PRF. To prevent development of resorption, calcium hydroxide was used as intracanal medicament and doxycycline was used to prevent surface resorption.

Conclusion: PRF is effective not only in promoting healing, bone deposition but also prevents secondary infection of the wound. Hence, it is simple, easy, and inexpensive biomaterial for treating intrusion injuries of teeth.

Clinical significance: Considering the various properties associated with PRF, it could be a key for treating other type traumatic injuries to teeth. Keywords: Complication, Intrusion, Prevention, PRF, Trauma International Journal of Clinical Pediatric Dentistry (2021): 10.5005/jp-journals-10005-2084
\end{abstract}

\section{INTRODUCTION}

The incidence of traumatic injuries is more in young children. ${ }^{1-3}$ Intrusion in children is relatively rare compared to the other trauma injuries. Intrusion is a result of impact of force axially leading to the tooth pushed into the socket. Unlike other injuries, the amount of energy of trauma is transmitted to all the components of the periodontium, pulp, and soft tissue. Hence, one of the factors influencing the healing depends on the extent of the injury of the above components. ${ }^{4}$ The pathological sequelae are gingival recession, root resorption (external resorption), ankylosis, and bone loss. Injury to the pulp can lead to the obliteration of the pulp, pulpal necrosis, and internal resorption.

The treatment modalities and prognosis depend on age, development stage of the root, and severity of intrusion. ${ }^{4}$ Intruded teeth are classified according to the degree of clinical displacement into three types, i.e., mildly intruded $(<3 \mathrm{~mm})$, moderately intruded (3-6 mm), and severely intruded $(>6 \mathrm{~mm}) .^{5}$ The treatment plan for mildly and moderately intruded teeth depends on the development of the root. If there is an open apex, spontaneous eruption is expected in mild-to-moderate intruded teeth. In closed apex, orthodontic extrusion is preferred. Surgical repositioning or extraction is the treatment of choice for severely intruded teeth. ${ }^{6}$ Prognosis of surgical repositioning of teeth is questionable.

This case report describes the management of a traumatically intruded mature permanent central incisor by surgical repositioning.

\section{Case Description}

A 9-year-old female patient reported to the private dental clinic with bleeding gums. She presented with a history of road

\begin{abstract}
1,6 Department of Pedodontics and Preventive Dentistry, Malla Reddy Institute of Dental Sciences, Hyderabad, Telangana, India

${ }^{2}$ Department of Conservative Dentistry and Endodontics, Bidar Institute of Medical Sciences, Bidar, Karnataka, India

${ }^{3}$ Department of Periodontology and Oral Implantology, Malla Reddy Institute of Dental Sciences, Hyderabad, Telangana, India

${ }^{4}$ Department of Oral Pathology and Microbiology, Malla Reddy Institute of Dental Sciences, Hyderabad, Telangana, India

${ }^{5}$ Department of Prosthodontics and Crown and Bridge, Malla Reddy Institute of Dental Sciences, Hyderabad, Telangana, India
\end{abstract}

Corresponding Author: Rajesh Ragulakollu, Department of Pedodontics and Preventive Dentistry, Malla Reddy Institute of Dental Sciences, Hyderabad, Telangana, India, email: ragrajeshr@gmail.com

How to cite this article: Ragulakollu R, Biradar N, Kukkunuru GT, et al. Role of Plasma-rich Fibrin in the Management of Intrusion Injuries of Teeth. Int J Clin Pediatr Dent 2021;14(6):820-824.

Source of support: Nil

Conflict of interest: None

traffic accident few hours back. On presentation, laceration of gingiva is seen from 21-22 and intruded 21 (Fig. 1A). Radiograph confirmed the clinical findings of intruded closed apex 21 with no root fractures (Fig. 1B). Since patient's guardian informed 22 is unerupted at the time of injury, it is not considered as intruded.

Labial and palatal infiltration with lidocaine with adrenaline is administered. No incision was given as there was a laceration. With the help of the periosteal elevator, palatal flap is reflected to expose the teeth (Fig. 2). With a gentle outward force, it is

(-) The Author(s). 2021 Open Access This article is distributed under the terms of the Creative Commons Attribution 4.0 International License (https://creativecommons. org/licenses/by-nc/4.0/), which permits unrestricted use, distribution, and non-commercial reproduction in any medium, provided you give appropriate credit to the original author(s) and the source, provide a link to the Creative Commons license, and indicate if changes were made. The Creative Commons Public Domain Dedication waiver (http://creativecommons.org/publicdomain/zero/1.0/) applies to the data made available in this article, unless otherwise stated. 
pushed incisally by comparing the incisal edge of the adjacent teeth (Fig. 3). Flexible splinting is done with a 28-guage stainless steel wire and a light cure composite. Access opening was done immediately after splinting and pulp was removed. Root canal is completely filled with calcium hydroxide with iodoform (Metapex, Meta Biomed Co. Ltd., Korea).

After 3 weeks, it was observed that there was a marked gingival recession suggesting bone loss labially (Fig. 4). Calcium hydroxide is removed with an $\mathrm{H}$ file and irrigated copiously with sodium hypochlorite. Biomechanical preparation was done and obturated with gutta-percha by lateral condensation technique. At the same time, patient is prepared for managing bone loss with platelet-rich fibrin (PRF). Local anesthesia is administered labially, labial flap is raised from 11 to 22 to facilitate complete coverage of the root. To promote secondary healing, the edges of the labial flap are severed.

Blood is collected from child's cubital vein of volume $20 \mathrm{~mL}$, collected in a glass test tube, and centrifuged at 4,000 rpm for 10 minutes in a centrifuge machine. PRF is collected with a nontoothed Adson forceps from middle of the test tube. After separating the fibrin clot, PRF is squeezed between two gauze pieces. This eliminates the fluids in the fibrin matrix, leaving fibrin membrane (Fig. 5).

The root surface is treated with a doxycycline $100 \mathrm{mg}$ vial for 5 minutes. After it has dried completely, fibrin membrane is placed onto the 11 and 22, sutured with a silk suture and coe pak is placed
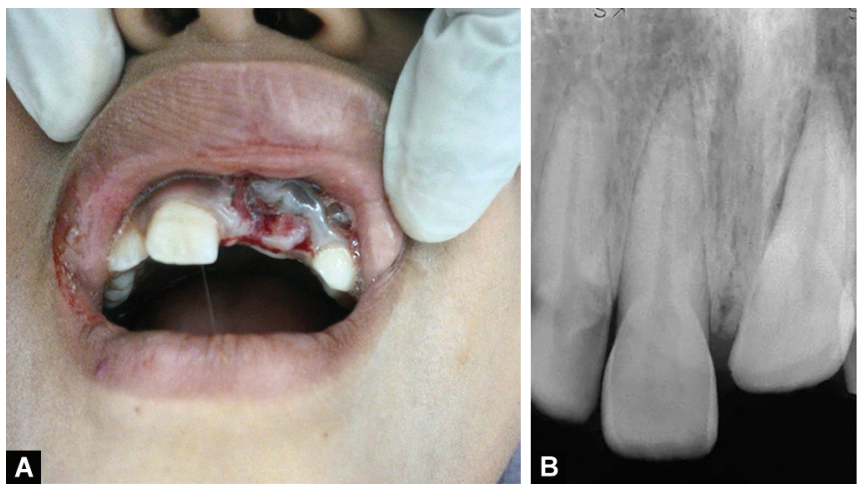

Figs 1A and B: Intruded tooth 21: (A) Preoperative clinical photograph: (B) X-ray

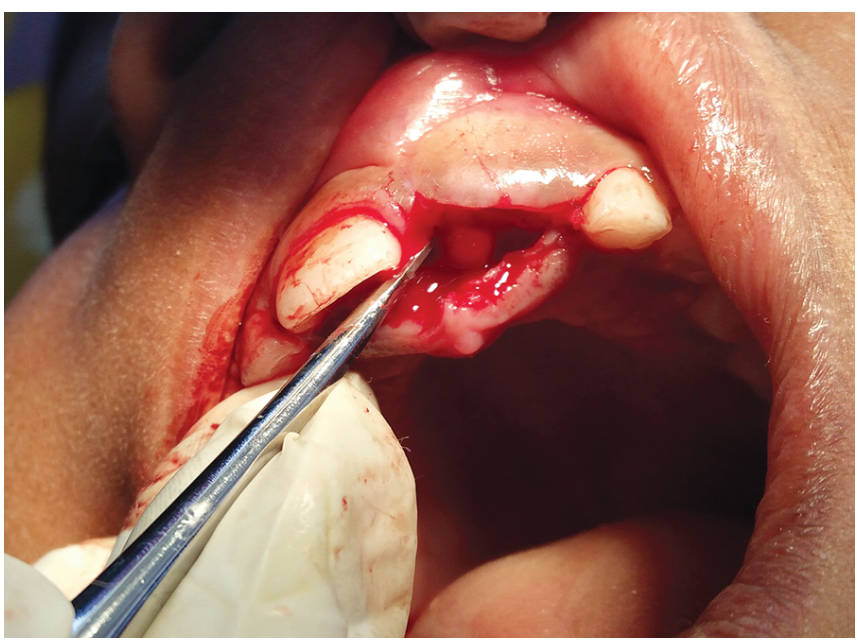

Fig. 2: Surgical extrusion of intruded teeth clinical photograph for 1 week (Fig. 6). After 1 week, both coe pak are removed. Patient is advised massage gums in downward directions after 1 week. Patient was asked to review after 1 month, but reviewed after 3 months and checked for the amount of the bone deposited. There was an incomplete bone deposition (Fig. 7). Gentle scaling and root planing were done. Splinting is removed and replaced with a complete acrylic crown and partial labial crown which distributes and reduces the forces transmitted. Patient is asked to review after 6 months. After 6 months, there was an evident reduction of gingival recession. Gingival curettage is done (Fig. 8). Patient is asked to review after 6 months.

After 6 months, there is bone deposition evident in radiograph interdentally and labially with a gingiva completely covering till cervical line (Fig. 9). Hence, no surgical entry was performed and there were no features of resorption.

\section{Discussion}

Intrusion is the severe form of tooth injury with a questionable prognosis due to the damage to all the components of the periodontium. Multiple factors determine the prognosis of the injury. ${ }^{7}$ Guidelines proposed are based on the extent of the injury. If the extent of intrusion of the tooth is greater than $6 \mathrm{~mm}$, it is considered to be severe. The treatment of choice is surgical extrusion only. ${ }^{6,8}$ It has a advantage of lesser time taken for restoring the normal occlusion and original anatomy of tooth thereby promoting better healing of surrounding tissues. ${ }^{9-11}$

Controversy still persists with few authors stating that the stating the surgical repositioning can aggravate the injury to the periodontal structures, increasing the possibility of postoperative complications such as external root resorption and loss of marginal bone support. ${ }^{12}$

In the case reported, the treatment is divided in three phases: First phase:

This phase aims at prevention of external root resorption and pulpal necrosis. To gain the endodontic access of the intruded teeth, surgical repositioning is done immediately. Removal of the pulp and surgical repositioning inhibit the initiation of the external root resorption and pulpal necrosis. ${ }^{13}$ Intracanal dressing with calcium hydroxide eliminates bacteria and has shown to arrest inflammatory resorption. This is attributed to the antibacterial property and diffusion into the dentinal tubules inducing denaturing effect in resorbing cells. ${ }^{13}$

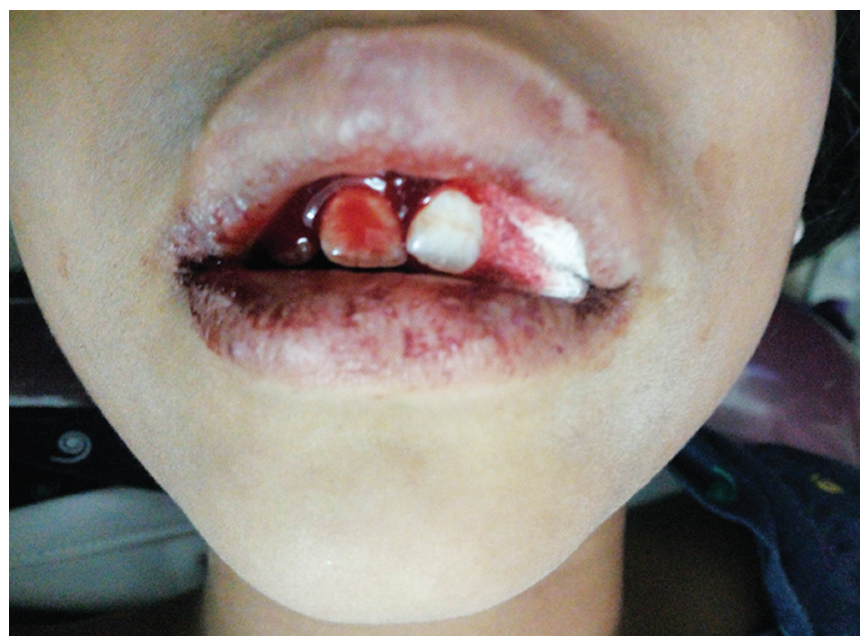

Fig. 3: Repositioned teeth clinical radiograph 

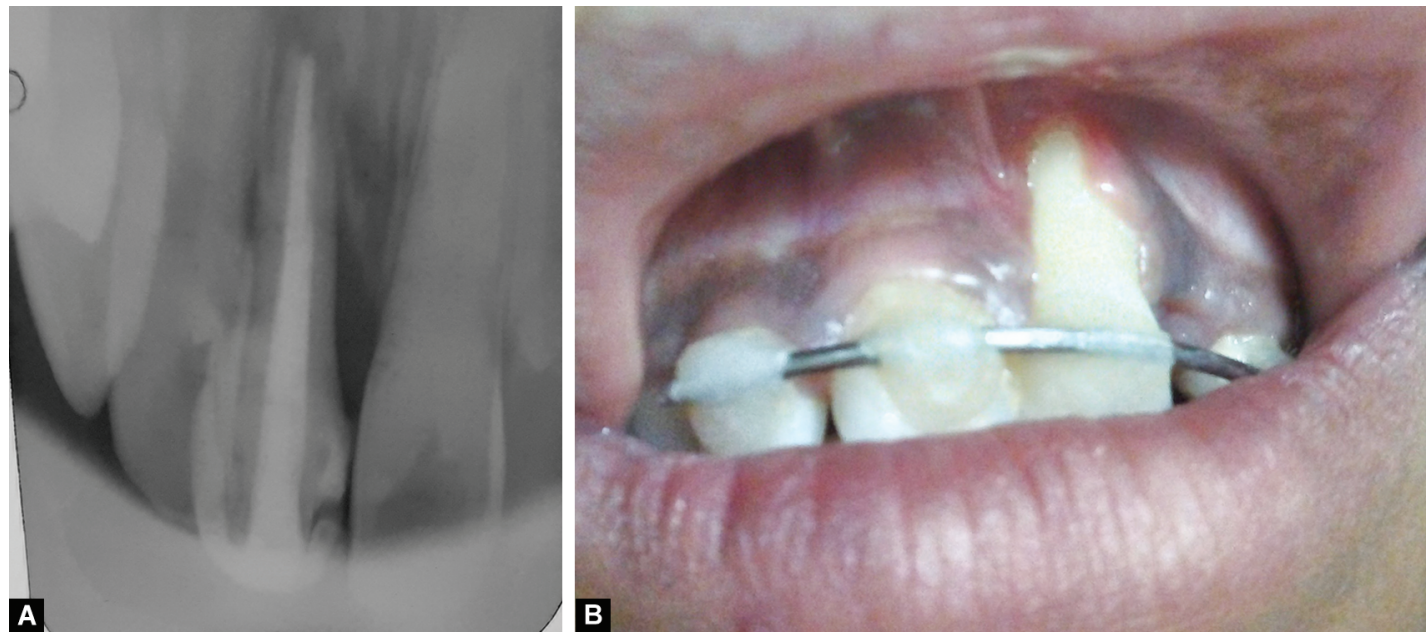

Figs 4A and B: (A) Marked gingival after 3 weeks clinical photograph; (B) Alveolar bone loss radiographic photograph
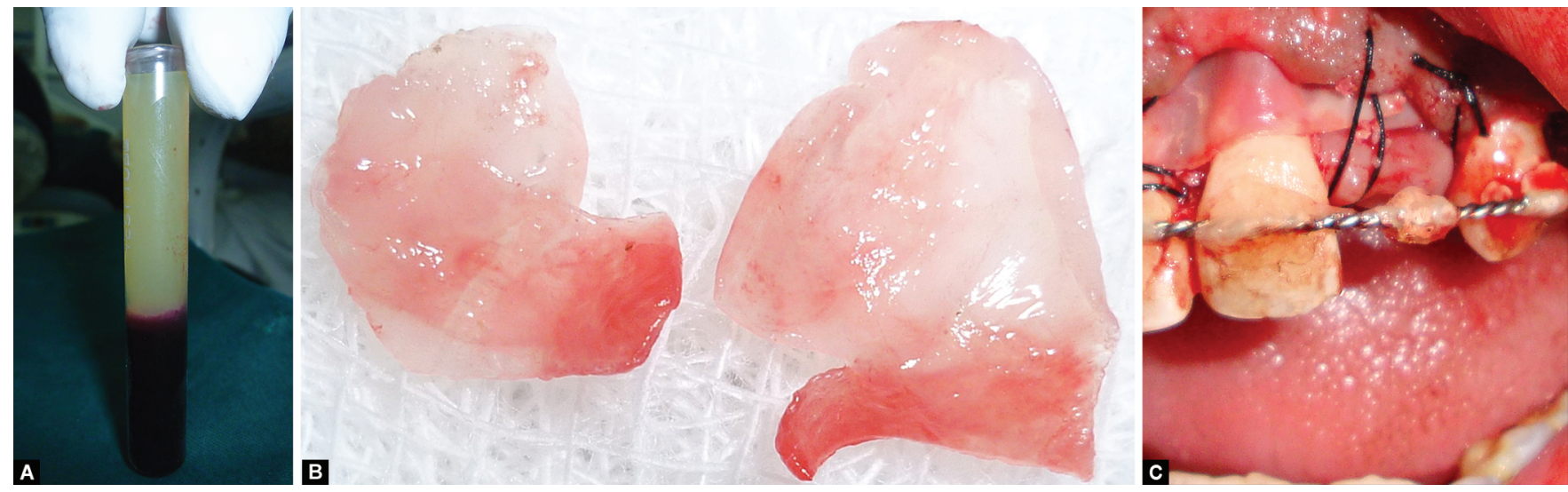

Figs 5A to C: (A) PRF membrane placed clinical photograph; (B) Centrifuged blood; (C) PRF membrane

\section{Second phase:}

Second phase targets developing or developed complications from first phase and alveolar bone loss. Time interval preferred is $2-4$ weeks.

Doxycycline has a long-lasting substantivity and bactericidal action eliminating the bacteria on the root surface as well as forms a bond with dentin, which is resistant to dissolution. ${ }^{14}$ This prevents inflammatory root resorption.

Platelet-rich fibrin is a fibrin matrix bed incorporating platelets, leukocytes, cytokines, and circulating stem cells. ${ }^{7,12}$ These biomaterials develop coherent healing system, without causing inflammatory excess.

Platelet-rich fibrin promotes wound healing, bone growth, and maturation. It can also be used as a membrane. Many clinical trials suggest the combination of bone grafts and PRF to enhance bone density. ${ }^{15}$

Third phase:

Third phase targets developing complications of second phase and internal or external resorption. It is ideally started after 6 months. External resorption has better prognosis than internal resorption. Early treatment prevents development of internal resorption. Both are diagnosed by radiograph or cone-beam computed tomography (CBCT). Triple antibiotic paste can be filled in the root canal, which prevents root resorption. In this case, there was no progression to third phase.
These phases are divided based on the sequence of development of complications and healing. Complexity of the healing in traumatic injuries is attributed involvement of multiple cellular systems with a variable healing. ${ }^{16}$ Intrusion causes alveolar bone loss, loss of periodontal ligament attachment, contusion, and ischemic damage to Hertwig's epithelial root sheath and pulpal ischemia. ${ }^{16}$ The healing capacity is influenced by the cell viability next to the cementum layer. ${ }^{16}$ In order to increase the cell motility angiogenesis, immunity, availability of stem cells, and wound protection are important factors.

For angiogenesis, it requires matrix acting as a mesh work for binding of various growth factors. PRF acts as a natural fibrin mesh, which facilitates microvascularization and epithelial cell migration to its surface thereby accelerating wound healing. The leukocyte content in this matrix protects the wound from infection which promotes healing. ${ }^{17}$

Platelet-rich fibrin during angiogenesis acts as mesh to stem cells, which promotes healing of tissues by conversion into localized tissue. These stem cells are numerous in number compared to adults in young children paving the path for easy and accelerated healing of tissues so also wide osseous defects. The fibrin matrix is associated with bone morphogenetic protein (BMP), which promotes osseous conductive properties..$^{18}$ Hence, it is clear that PRF could be important element in addressing complications associated with intrusion. 

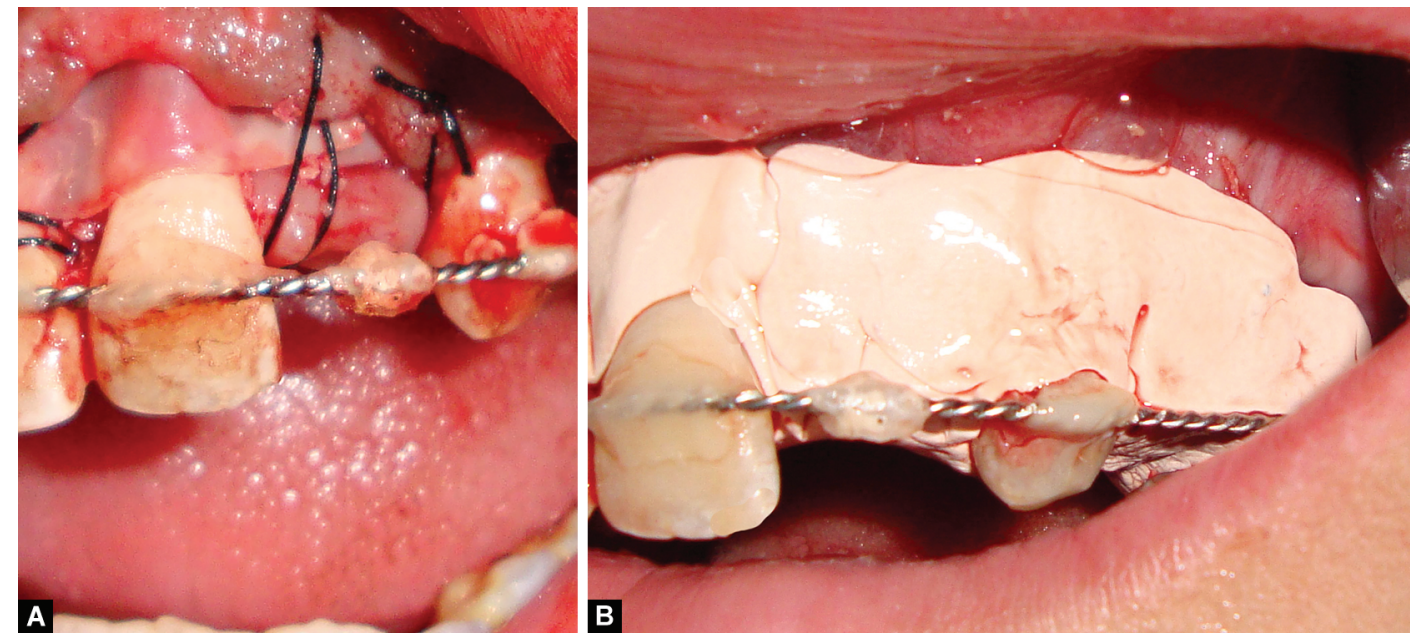

Figs $6 \mathrm{~A}$ and $\mathrm{B}$ : Clinical photograph with Coe Pak

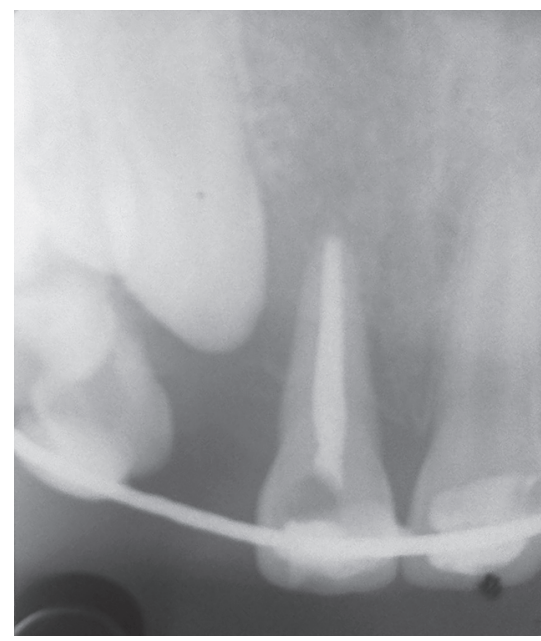

Fig. 7: Radiograph after 1 month

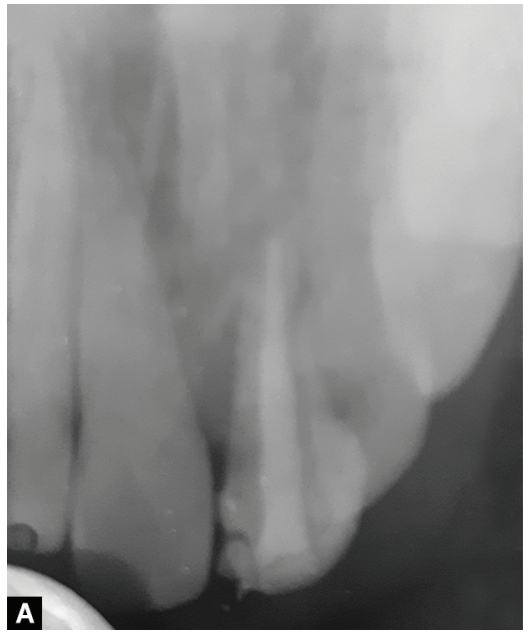

Figs $9 \mathrm{~A}$ and B: Postoperative clinical photograph

\section{Conclusion}

The prognosis of severe intruded traumatic injuries is generally poor. A number of factors influence the outcome in intrusion. Furthermore, there is no established treatment protocol for

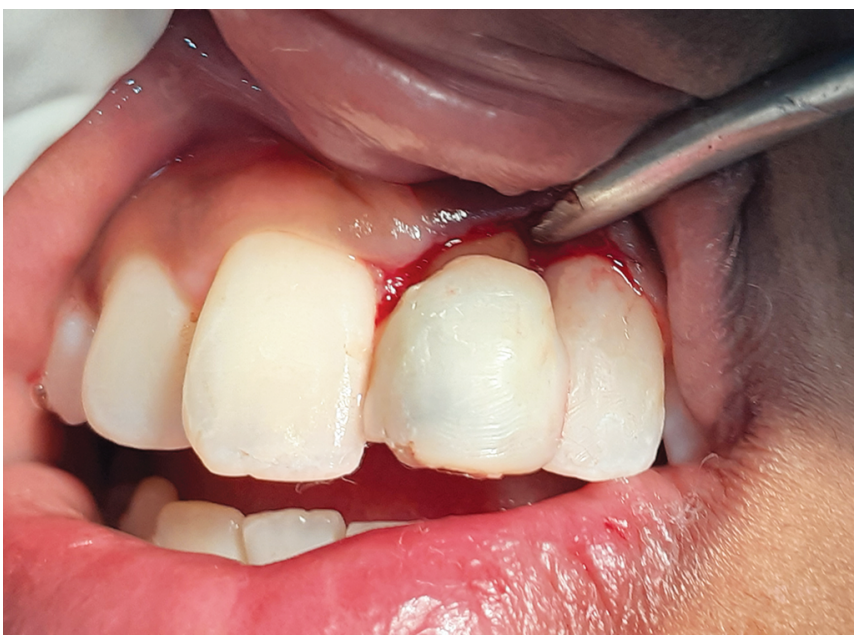

Fig. 8: Clinical picture after 6 months

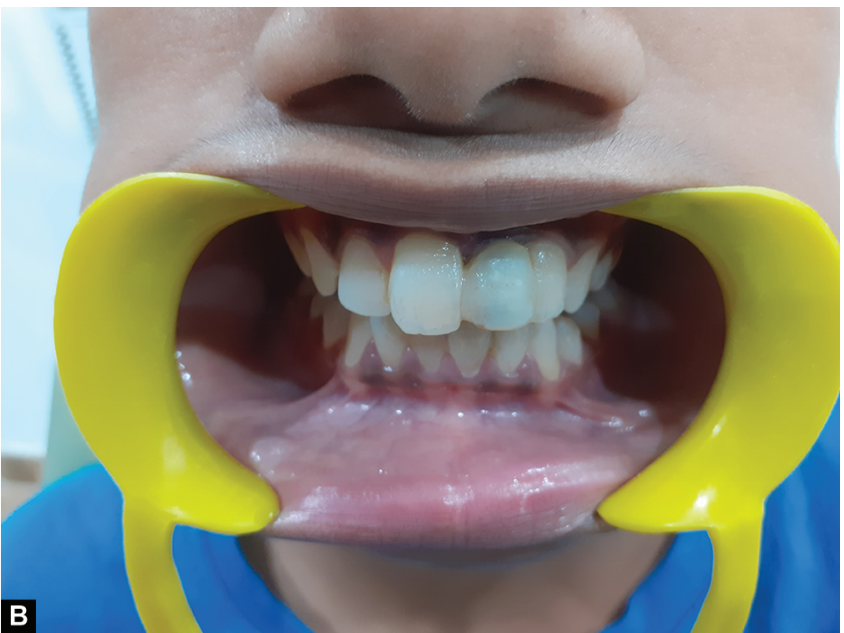

intrusion injuries during the treatment. Clinical monitoring and symptomatic treatment was the only method followed until today. In this case report, we treated successfully with PRF taking to consideration various treatment options from systematic analysis and case reports with further complications. Further studies are 
required to evaluate efficacy of PRF in intrusion. Though we have applied this method to surgical repositioning, this can be followed to other treatment strategies such as orthodontic extrusion and spontaneous re-eruption.

\section{References}

1. Snawder KD. Traumatic injuries to teeth of children. J Prev Dent 1976;3(6):13-20.

2. Andreasen JO, Ravn JJ. Epidemiology of traumatic dental injuries to primary and permanent teeth in a Danish population sample. Int J Oral Surg 1972;1(5):235-239. DOI: 10.1016/s0300-9785(72) 80042-5

3. Hedegård B, Stålhane I. A study of traumatized permanent teeth in children 7-15 years. I. Sven Tandlak Tidskr 1973;66(5):431-452.

4. Andreasen JO, Bakland LK, Andreasen FM. Traumatic intrusion of permanent teeth. Part 2. A clinical study of the effect of preinjury and injury factors, such as sex, age, stage of root development, tooth location, and extent of injury including number of intruded teeth on 140 intruded permanent teeth. Dent Traumatol 2006;22(2):90-98. DOI: 10.1111/j.1600-9657.2006.00422.x

5. Andreasen FM, Pedersen BV. Prognosis of luxated permanent teeth-the development of pulp necrosis. Endod Dent Traumatol 1985;1(6):207-220. DOI: 10.1111/j.1600-9657.1985.tb00583.x

6. Bakland LK. Dental trauma guidelines. J Endod 2013;39(3 Suppl):S6-S8. DOI: 10.1016/j.joen.2012.10.021

7. Humphrey JM, Kenny DJ, Barrett EJ. Clinical outcomes for permanent incisor luxations in a pediatric population. I. Intrusions. Dent Traumatol 2003;19(5):266-273. DOI: 10.1034/j.1600-9657. 2003.00207.x

8. Tronstad L, Trope M, Bank M, et al. Surgical access for endodontic treatment of intruded teeth. Endod Dent Traumatol 1986;2(2):75-78. DOI: 10.1111/j.1600-9657.1986.tb00130.x
9. Calişkan MK. Surgical extrusion of a completely intruded permanent incisor. J Endod 1998;24(5):381-384. DOI: 10.1016/S0099-2399(98)80140-4

10. Calişkan MK, Gomel M, Türkün M. Surgical extrusion of intruded immature permanent incisors: case report and review of the literature. Oral Surg Oral Med Oral Pathol Oral Radiol Endod 1998;86(4):461-464. DOI: 10.1016/s1079-2104(98)90374-2

11. Ebeleseder KA, Santler G, Glockner K, et al. An analysis of 58 traumatically intruded and surgically extruded permanent teeth. Endod Dent Traumatol 2000;16(1):34-39. DOI: 10.1034/j.1600-96 57.2000.016001034.x

12. Andreasen JO, Andreasen FM. Essentials of traumatic injuries to the teeth: a step-by-step treatment guide. Copenhagem: Munksgaard; 2000. DOI: $10.1002 / 9780470698822$

13. Massarstrom LE, Blomlof LB, Feiglin B, et al. Effect of calcium hydroxide treatment on periodontal repair and root resorption. Endod Dent Traumatol 1986;2(5):184-189. DOI: 10.1111/j.1600-9657.1986. tb00142.x

14. Demirel K, Baer PN, McNamara TF. Topical application of doxycycline on periodontally involved root surfaces in vitro: comparative analysis of substantivity on cementum and dentin J Periodontol 1991;62(5):312-316. DOI: 10.1902/jop.1991.62.5.312

15. Sunitha Raja V, Munirathnam Naidu E. Platelet-rich fibrin: evolution of a second-generation platelet concentrate. Indian J Dent Res 2008;19(1):42-46. DOI: 10.4103/0970-9290.38931

16. Andreasen JO, Løvschall H. Response of oral tissues to trauma. In: Andreasen JO, Andreasen FM, Andersson L (Eds). Textbook and color atlas of traumatic injuries to the teeth, 4th edition. Oxford: Blackwell; 2007. pp. 62-113.

17. Andreasen JO. Pulp and periodontal tissue repair - regeneration or tissue metaplasia after dental trauma. A review. Dent Traumatol 2012;28(1):19-24. DOI: 10.1111/j.1600-9657.2011.01058.x

18. Kawamura $M$, Urist MR. Human fibrin is a physiologic delivery system for bone morphogenetic protein. Clin Orthop 1988;235:302-310. DOI: 10.1097/00003086-198810000-00031 